\title{
Aboveground Biomass and Carbon content of a cocoa - Gliricida sepium agroforestry system in Ghana
}

\author{
S. OWUSU, L. C. N. ANGLAAERE \& S. ABUGRE* \\ (S. O. \& L. C. N. A.: CSIR-Forestry Research Institute of Ghana (CSIR-FORIG), Kumasi, \\ Ghana.; S. A.: School of Natural Resources, University of Energy and Natural Resources, \\ Sunyani, Ghana.) \\ *Corresponding author's email: simon.abugre@uenr.edu.gh
}

\begin{abstract}
To help overcome the challenge faced in re-establishing cocoa in degraded lands, some agroforestry trials were established with exotic leguminous tree species to determine their suitability for cocoa cultivation. However, our understanding of biomass accumulation and carbon sequestration in such specific agroforestry practices is still limited. In this study the above-ground biomass and carbon storage and partitioning in a gliricidia-cocoa agroforestry system was investigated. Above-ground biomass accumulation and carbon stock varied significantly between the components of the system, with the gliricidia shade trees having the highest values and the cocoa trees having the lowest. The inclusion of the gliricidia shade trees in the system increased above-ground biomass and carbon capture of the system by some $60 \%$, a greater proportion of which was contained in the branches of the shade trees. This pattern of dry matter distribution makes the species appropriate for use as a biomass producing species in agroforestry systems and demonstrates the potential of cocoa agroforestry systems for capturing and storing more atmospheric carbon than sole cocoa systems.
\end{abstract}

Original scientific paper. Received 2 Mar 2015; revised 19 Apr 2016

\section{Introduction}

Cocoa (Theobroma cacao L.) agroforests are a common farming system in the humid zone of West and Central Africa, in which forest trees provide shade and other environmental services as well as marketable products (Oke \& Odebiyi, 2007). Traditionally, small holder cocoa farmers establish their farms by removing the forest under-storey and thinning the forest canopy so that cocoa seedlings can grow into productive trees (Duguma et al., 2001).

However, in Africa cocoa cultivation is generally considered to be a major cause of deforestation since the cocoa trees are often planted on newly cleared forest land (Dixon et al., 2001). In Ghana, for instance, it is estimated that $80 \%$ of the forest area has disappeared since cocoa trees were introduced (Cleaver, 1992). Presently, the traditional cocoa-growing areas in many places are degraded and have been abandoned. Re-establishing cocoa in these areas has proven difficult due to low soil fertility, bush fires, diseases and pest, and inappropriate vegetation cover to provide shade for young cocoa (Adams, 1962; Ayanjala, 1983). Depletion of soil carbon has been documented to result in decreased productivity, poor soil physical and chemical properties,

Ghana Jnl Agric. Sci. 53, 45 - 60

GJAS is an Open Access Journal and distributed under the terms of the Creative Commons (CC) License [CC BY 4.0] 
and negative secondary environmental impacts (Jose \& Bardhan, 2012). To help overcome the challenge faced in re-establishing cocoa in these degraded lands, some agroforestry trials were established with exotic leguminous tree species, including Gliricidia sepium (Jacq.) Walp, to determine their suitability for cocoa cultivation in Ghana. These species are supposed to replenish the soils through nitrogen fixation and nutrient cycling, while providing some other benefits such as fuel wood and fodder, among others, for the farmers. It has been well established that conversion of degraded agricultural soils into agroforestry systems can regenerate soil productivity (Jose \& Bardhan, 2012).

It has been pointed out that agroforestry systems have the potential to combine agricultural production, the supply of woody biomass and the provision of numerous environmental services, such as carbon storage, conservation of biodiversity and soil protection (Jose, 2009). Aboveground woody biomass plays a decisive role considering the economic value of the agroforestry systems as well as the carbon storage. Production systems like agroforestry have to meet ecological and socio-economic sustainability as a condition for acceptance and implementation by producers and society (Abrahamson et al., 1998). As has been highlighted, aboveground woody biomass of agroforestry systems plays a decisive role for the assessments of the economic viability and several ecosystems studies on carbon sequestration, energy and nutrients flows, forest and greenhouse gas inventories (Afas et al., 2008). Biomass studies in agroforestry systems in Ghana are still quite limited. However, a number of biomass studies have been carried out for various tree-crop combinations elsewhere that demonstrate and highlight the importance of these studies for ecosystem management. For instance, Tandon et al., (1991), estimated bole biomass and aboveground biomass of Populus deltoides trees planted in agroforestry with a spacing of $5 \mathrm{~m} \times 5 \mathrm{~m}$ (400 trees/ha). Bole biomass was $17.42,37.47$ and $47.80 \mathrm{Mg} \mathrm{ha}^{-1}$ at the age of 3, 5 and 7 years respectively. The total aboveground biomass (boles, branches and foliage) was estimated to be $26.91,52.43$ and $65.76 \mathrm{Mg} \mathrm{ha}^{-1}$ for 3, 5 and 7-yr-old plantations respectively. Negi \& Tandon, (1997), studied the biomass production of $P$. deltoides plantations having 917, 500, 489 and 783 trees ha $^{-1}$ for 3, 5, 7 and 9-yr-old tree respectively. The standing bole biomass was in the order of 7.1, 15.3, 44.4 and $83.2 \mathrm{Mg} \mathrm{ha}^{-1}$ respectively. According to Lodhiyal et al., (1992), total aboveground biomass of $P$. deltoides varied from 67.6 to $149.3 \mathrm{t} \mathrm{ha}^{-1}$, of which bole biomass range was $41.3-101.8 \mathrm{Mg} \mathrm{ha}^{-1}$ for 5- 9-yrold plantations having a density of 400 trees/ ha. Lodhiyal et al., (1995) again studied the dry-matter production in poplar and found that in an agrisilviculture system, the estimated carbon stock in stem wood and aboveground biomass was 42.36 and $65.62 \mathrm{Mg} \mathrm{ha}^{-1}$ respectively, for 8 - year old plantations. Total carbon stock as tree biomass in agrisilviculture systems was estimated to be $83.07 \mathrm{Mg} \mathrm{ha}^{-1}$ at a rotation period of 7 years.

Utilization of trees and shrubs has long been recognized to be one of the most effective means of improving both the supply and the quality of forage in tropical smallholder livestock systems, especially during the dry season (Gutteridge \& Shelton, 1994; Robinson, 1985). Green fodder from nitrogen-fixing leguminous trees, in particular, contains much higher levels of protein than the poor quality basal feeds (grasses and crop residues such as stover) available during the dry season, and persists for longer owing to the trees' deep roots (Rizvi, 2011). 
As pointed out by Dhyani et al., (2009), agroforestry is an ideal option to increase productivity of wastelands, increase tree cover outside the forest and reduce human pressure on forests under different agro-ecological regions, and is then a viable option to prevent and mitigate climate-change effects. Cocoa based agroforestry systems are credited for stocking significant amounts of carbon and hence have the potential to mitigate climate change. Global climate change and energy security are two key issues that are at the forefront of environmental discussions the world over. Although they bring up unique challenges, global warming and energy security are inextricably interlinked (Jose \& Bardhan, 2012). Studies have revealed that deforestation and conversion of forest to agricultural lands contribute $17.4 \%$ of global greenhouse gas emissions (IPCC, 2007). Many observers see agroforestry systems as presenting a promising alternative to common-practice agriculture in the tropics because they can serve as carbon sinks and biodiversity pools and may play a significant role in mitigating or adapting to climate change (Tscharntke et al., 2011; Soto-Pinto et al., 2010; Nair et al., 2009). A number of studies have estimated C stocks of different agroforestry systems in other settings outside Ghana. Carbon stocks in shaded agroforestry systems with perennial crops, such as coffee (Coffea arabica L.), rubber (Hevea brasiliensis Muell.-Arg.), and cocoa may vary between 12 and $228 \mathrm{Mg} \mathrm{ha}^{-1}$, depending on system complexity and age, a could help to mitigate climate change (Schroeder, 1994; Dixon, 1995; Albrecht \& Kandji, 2003; Montagnini \& Nair, 2004; Nair et al., 2009). In a study conducted to assess carbon accumulation in agroforestry systems in India, Singh \& Lodhiyal, (2009), have estimated carbon stock in 8-yrold $P$. deltoides (poplar) agroforestry plantations to be $47.86 \mathrm{Mg} \mathrm{ha}^{-1}$ in bole wood alone and $96.23 \mathrm{Mg} \mathrm{ha}^{-1}$ in total biomass of trees. Fang et al., (2007), comparing carbon storage in P. deltoides plantations with different stocking densities, found that total carbon storage in the poplar plantation of 1,111 stems $\mathrm{ha}^{-1}$ was the highest and about $72.0 \mathrm{Mg} \mathrm{ha}^{-1}$, which was $5.4 \%, 11.9 \%$ and $24.8 \%$ higher than that in plantations of 833,625 and 500 stems $\mathrm{ha}^{-1}$ respectively, clearly indicating the influence of tree stocking density on $\mathrm{C}$ stock. In a study by Rizvi et al., (2011) they recorded a standing/total carbon stock of $3.78-11.62 \mathrm{Mg}$ $\mathrm{C} \mathrm{ha} \mathrm{C}^{-1}$ under poplar-based agroforestry in the upper Gangetic region, where 70 million poplar trees are standing with agricultural crops.

Woody biomass constitutes the major source of energy in the developing countries of the world. In Ghana, fuelwood shortage has been identified as a pressing domestic problem affecting many households (Otsyina, 1989). The need to establish energy plantations has been recognized. Several multipurpose tree species, including G. sepium, have been recommended in Ghana for use in different land use systems to reduce or solve the pressing fuelwood problems which face many households in the country (Quashie-Sam et al., 1990), as well as mitigate soil fertility problems and provide valuable fodder for livestock. One of the commodities agroforestry is well suited to producing is biomass for bio power and biofuels (Jose et al., 2012). Heavy reliance on foreign based fossil fuels has sparked an interest in domestic renewable energy sources in many countries, including Ghana.

It has been noted that the relative amount of biomass present in the various organs, i.e. biomass allocation, is not fixed but may vary over time, across environments and among species (Poorter, et al., 2012). A quantitative understanding of such patterns is of fundamental importance to plant ecology and evolution, 
and has many uses in agricultural practice and implementation, as these patterns, and the extent to which they vary among species, set limits on biomass production and utilization (Niklas, 1994; Reich, 2002). Scientific studies and information on the growth, dry matter production and carbon accumulation of agroforestry systems in Ghana is very limited. In 2006, the Ghana Cocoa Growers Association, in association with Cadbury Ghana Ltd, established a cocoa agroforestry plot in Bontomuruso in the then Atwima District of Ghana, using Gliricidia sepium (Jacq.) Walp as the main shade tree with the cocoa. In the system as exists in Bontomuruso, it is expected that the G. sepium shade trees will be cut back at one stage to manage the shade level and the wood used for fuelwood energy. While growth data will help in evaluating the economic rate of development of such multi-strata systems, estimates of tree biomass and distribution are useful in studies of biological productivity and nutrient requirement and bioenergy production potential of such ecosystems. Information on the amount of dry matter and carbon, and their partitioning at stand level, is therefore essential for developing models of system structure and function in such agroforestry plantations. It is important to understand, given the current circumstances, the contribution of Gliricidia-cocoa agroforestry systems within local, regional or global carbon cycles (Smiley \& Kroschel, 2008).

The general objective of this study, therefore, was to assess the potential contribution of a planted cocoa agroforestry system to the biomass and carbon budget. The specific objectives were to:

(i) determine the above-ground dry matter of the system components in a Gliricidia-cocoa agroforestry system and determine carbon content of the Gliricidia and cocoa trees within the agroforestry system.

\section{Materials and methods}

The study area

The study was carried out in Bontomuruso in the Atwima Mponua District of the Ashanti Region of Ghana. Bontomuruso is about $80 \mathrm{~km}$ from Kumasi, the Ashanti Regional capital. The District lies approximately on latitude $6^{\circ} 75^{\prime} \mathrm{N}$ and between longitudes $1^{\circ} 45^{\prime}$ and $2^{\circ} 00^{\prime}$ 'West, and is one of the largest Districts in the Ashanti Region. Bontomuruso is located on latitude $6^{\circ}$ $33^{\prime} 0$ " $\mathrm{N}$ and longitude $1^{\circ} 0333^{\prime} 60$ ' W. It is a predominantly farming community with cocoa as the major cash crop. The study was carried out in November 2012 on a research farm established by the Ghana Cocoa Growers and Researchers Association (GCGRA). It consists of cocoa planted at a regular spacing of $3 \mathrm{~m} \times 3 \mathrm{~m}$ (giving an initial stocking of 1,111 trees $\mathrm{ha}^{-1}$ ), with Gliricidia sepium as the shade tree planted at a spacing of $6 \mathrm{~m} \times 6 \mathrm{~m}$ (i.e. an initial stocking of 277 trees $\mathrm{ha}^{-1}$ ). Since establishment, the Gliricidia has not been cut back and now forms an almost closed canopy above the cocoa trees. Mean stand height was estimated to be approximately $9.26 \pm 0.42 \mathrm{~m}$.

Bontomuruso lies within the wet semi-equatorial climatic zone and is marked by a double maxima rainfall. Mean annual rainfall ranges between $1700 \mathrm{~mm}$ and $1850 \mathrm{~mm}$. The main rainfall season occurs from March to July with a minor season starting from September and lasting until November. The main dry season lasts from December to mid-March, during which period the harmattan winds blow over the area. Temperatures are uniformly high throughout the year, with mean monthly minimum and maximum temperatures of $27^{\circ} \mathrm{C}$ 
and $31^{\circ} \mathrm{C}$ occurring in August and March respectively. The relative humidity is generally high $(72 \%-90 \%)$ throughout the year (Hall \& Swaine, 1981).

\section{Climate and ecology of the study site}

Bontomuruso is located within the moist semi-deciduous ecological zone which is characterized predominantly by the Celtis-Triplochiton Floristic Association as described by Taylor, (1960). This is the most extensive of all the forest types in Ghana, and trees here become taller than in any other (Hall \& Swaine, 1981). The vegetation in this zone is further divided into a slightly drier North-West subtype (MSNW), within which Bontomuruso is located. Fig. 1 shows the forest types in Ghana, and the location of the study area relative to Kumasi, the Ashanti regional capital.

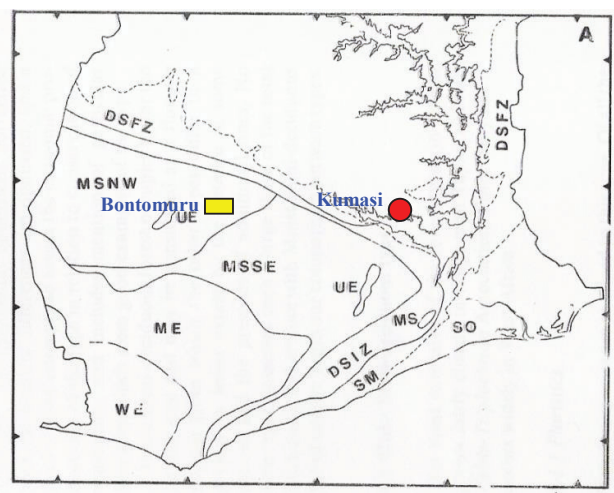

Fig. 1. Forest zones of Ghana - showing location of study site.

$\mathbf{D S F Z}=$ Dry Semi-deciduous Fire Zone; $\mathbf{D S I Z}=$ Dry Semi-deciduous Inner Zone; MSNW = Moist Semi-deciduous South West; MSSE = Moist Semi-deciduous South East; $\mathbf{M S}=$ Moist Semi-deciduous; $\mathbf{M E}=$ Moist Evergreen; $\mathbf{W E}=$ Wet Evergreen; $\mathbf{U E}=$ Upland Evergreen; $\mathbf{S M}=$ Southern Marginal; $\mathbf{S O}=$ Southern Outlier. (Adapted from Hall and Swaine, 1981).
The moderate rainfall within the moist semi-deciduous forest zone leads to more depletion of soil nutrients than in types of lower rainfall. Base saturation is generally high, however, $(60$ to $80 \%$ ) providing a $\mathrm{pH}$ of about $5-6$. Total exchangeable bases (TEB) are generally below $10 \mathrm{~m}$ - equiv/100 g soil, but this appears adequate for the considerable tree growth characteristic of the MSNW. The type as a whole has only a moderate elevation of $150-600 \mathrm{~m}$, with higher elevations within the area carrying a forest of distinct type - Upland Evergreen (Hall \& Swaine, 1981).

The moist semi-deciduous forest zone is the most productive in the forest zone. The soil here is ideal for most of the forest zone crops, including cocoa. Cocoa and other farms are very much in evidence all over the moist semi-deciduous forest type, and there is a great demand for more farmland. Although the type is well supplied with forest reserves, most have been heavily exploited for timber (Hall \& Swaine, 1981). Pressure on these reserves from both timber contractors and farmers is increasing.

\section{Experimental procedure}

Biomass estimation

To estimate the biomass for the cocoa and the Gliricidia trees a plot of $60 \mathrm{~m} \times 60 \mathrm{~m}$ was demarcated in a well-stocked portion of the farm. Diameter at breast height (Dbh at 1.3 $\mathrm{m}$ ) of all Gliricidia and cocoa trees within the plot were measured with a digital caliper. The Dbh values for the Gliricidia and the cocoa trees in the plot were grouped into ten diameter classes, using one-tenth $\left(1 /{ }_{10}\right.$ th $)$ of the stand diameter range as the class interval. The stand diameter range for each species was calculated by subtracting the smallest diameter from the biggest diameter for each species. To obtain the class interval for the ten diameter classes, 
the diameter range for each species was then divided by ten. Mean diameter for each of the ten Dbh classes was further calculated by summing the Dbh values for all the trees in each of the Dbh classes and dividing by the number of trees in each class. Subsequently, ten trees of each species in the plot, selected to represent as closely as possible the mean diameter of each of the ten diameter classes for each species, were cut as close to ground level as possible (generally at $5 \mathrm{~cm}$ from the ground), using a chainsaw machine. Each felled tree was sorted into the three main components; bole, branches and foliage and each component was cut into small pieces for easy weight measurement. Samples were taken to the laboratory of the Forestry Research Institute of Ghana (FORIG) for the determination of dry weight and carbon content. In the laboratory, samples of the boles, branches and leaves of each sample tree were immediately put into envelops and dried in an oven to constant weight at $70^{\circ} \mathrm{C}$ and reweighed.

\section{Carbon estimation}

The carbon concentration of different tree parts is rarely measured directly, but generally assumed to be $50 \%$ of dry weight (Stephens, 2006). Hence in this study, the aboveground carbon content of the Gliricidia and cocoa trees was calculated by assuming that the carbon content is $50 \%$ of the dry weight of the total aboveground biomass (Ravindranath et al., 1997; Brown \& Lugo, 1982; Schroeder, 1992) of each tree component.

\section{Dry weight determination}

The dry weight : fresh weight ratios of the various component samples (i.e. stem, branches and leaves) were determined using the formula: Dry weight ratio $(\mathrm{DwR})=$ Sample oven dry weight . (Eqn. 1)
These ratios were then used to determine the dry weight of the component parts (stem, branches and leaves) of each of the felled sample trees, using the formula:

$$
\mathrm{Cdw}=\mathrm{Cfw} \times \mathrm{DwR}
$$

Where: $\mathrm{Cdw}=$ Total component dry weight (e.g. Total Stem, or Branches or Leaves dry weight) of sample tree

$\mathrm{Cfw}=$ Total component fresh weight

DwR $=$ Dry weight ratio, determined in Eqn 1 above

Total tree biomass was calculated as the sum of the dry weights of the various component parts of each tree. The total stand biomass was then calculated as the sum of products of the mean tree values and the number of stems in each of the Dbh classes, and expressed on per hectare basis as described by Nwoboshi (1985) and Nolte, et al., (2003).

\section{Data analysis}

Basal area (BA) per mean tree for each species was calculated as

$$
\mathrm{BA}\left(\mathrm{m}^{2}\right)=\pi(\mathrm{dbh})^{2}\left(\mathrm{~cm}^{2}\right) / 40000 .
$$

This was then multiplied by the number of trees in each Dbh class and summed to get BA per plot, and further extrapolated to obtain $\mathrm{Ba}-$ $\mathrm{sal} / \mathrm{ha}$ for each species. Total aboveground biomass and carbon content per hectare for the cocoa and Gliricidia trees, as well as biomass and carbon partitioning within the various tree components were calculated. Biomass and carbon content of the various tree components for the two species were compared with each other using an analysis of variance followed by Tukey's test at $\alpha=0.05$ (Martins \& Santos 1999). 


\section{Results}

Growth parameters of the system components The initial planting density for cocoa and $G$. sepium was 1111 and 277 trees/ha respectively. However, the density of the cocoa trees at the time of the study, eight (8) years on, was $61.48 \%$, or 683 trees/ha of the initial stocking, while that of the G. sepium trees was $73.65 \%$, or 204 trees/ha, on this site. Mean tree height for the $G$. Sepium trees was $9.26 \pm 0.42 \mathrm{~m}$ and this was significantly higher than that for cocoa which was $4.03 \pm 0.3 \mathrm{~m}(\mathrm{P}=0.041)$. While mean Dbh was $28.33 \pm 2.47 \mathrm{~cm}$ and $16.85 \pm$ $1.35 \mathrm{~cm}$ respectively for $G$. sepium and cocoa, and this was also significant $(\mathrm{P}=0.0408)$. Stand diameter range for the cocoa trees was $13.74 \mathrm{~cm}$ while that for $G$. sepium was 25.93 $\mathrm{cm}$. Mean basal area/tree for $G$. sepium trees was $0.0509 \pm 0.019 \mathrm{~m}^{2}$ and was found to be significantly higher than that for cocoa which was $0.0237 \pm 0.004 \mathrm{~m}^{2}$. However, stand basal area/ha for cocoa was $16.21 \pm 1.25 \mathrm{~m}^{2}$ and was not significantly different from the stand basal area for $G$. sepium which was $10.38 \pm 1.16 \mathrm{~m}^{2}$ (Table 1).

TABLE 1

Growth parameters of cocoa and $\boldsymbol{G}$. sepium trees in an agroforestry system in Bontomuruso, Ghana.

\begin{tabular}{lll}
\hline Parameter & G. sepium & T. cacao \\
\hline Mean height $(\mathrm{m})$ & $9.26 \pm 0.42^{\mathrm{a}}$ & $4.03 \pm 0.3^{\mathrm{b}}$ \\
Mean Dbh $(\mathrm{cm})$ & $28.33 \pm 2.47^{\mathrm{a}}$ & $16.85 \pm 1.35^{\mathrm{b}}$ \\
No. of trees $/ \mathrm{ha}$ & 204 & 683 \\
\hline Basal area/ha $\left(\mathrm{m}^{2}\right)$ & $10.38 \pm 1.16^{\mathrm{a}}$ & $16.21 \pm 1.25^{\mathrm{a}}$ \\
\hline
\end{tabular}

\section{Aboveground biomass accumulation and partitioning}

The partitioning of biomass in the cocoa and G. sepium trees is presented in Table 2. G. se- pium produced significantly higher dry weight per tree $(48.24 \pm 11.05 \mathrm{~kg})$ than the cocoa $(12.11 \pm 2.61 \mathrm{~kg})(\mathrm{P}=0.005)$. In terms of biomass distribution per tree, it was observed that as much as $46.54 \%$ (or $22.45 \pm 6.89 \mathrm{~kg}$ ) of the total mean tree dry weight for G. sepium was allocated to the branches and 44.34\% (21.39 \pm $3.79 \mathrm{~kg})$ to boles, with only $9.12 \%$ (4.40 \pm 0.66 $\mathrm{kg}$ ) of the total biomass allocated to the foliage (Table 2). On the other hand, a comparatively higher proportion of the biomass produced per cocoa tree was allocated to the foliage $(38.23 \%$ or $4.63 \pm 1.19 \mathrm{~kg}$ ) compared to G. sepium. Unlike in the $G$. sepium, bole dry matter per cocoa tree $(4.93 \pm 0.96 \mathrm{~kg} /$ tree or $40.71 \%)$ was higher than branch dry matter $(2.95 \pm 0.47 \mathrm{~kg} /$ tree or $24.36 \%$ ) (Table 2). However, for the larger diameter cocoa trees, the foliage dry matter was higher than the bole and branches dry matter (Fig. 1), unlike in the G. sepium where the branches had a higher dry matter per tree than the other tree components (Fig. 2). It was observed that G. sepium produced significantly higher bole and branch biomass per tree than the cocoa. However, there was no significant difference between foliage biomass per tree for both species.

The distribution of total aboveground stand biomass for the G. sepium and cocoa trees is shown in Table 3 and Fig. 3. A total above ground biomass of $10.26 \pm 0.57 \mathrm{Mg} \mathrm{ha}^{-1}$ was obtained for the G. sepium trees in the agroforest. Stem biomass accounted for an average of $31.10 \%\left(3.19 \pm 0.18 \mathrm{Mg} \mathrm{ha}^{-1}\right)$ while branch and foliage biomasses accounted for an average of $61.59 \%\left(6.32 \pm 0.36 \mathrm{Mg} \mathrm{ha}^{-1}\right)$ and $7.31 \%\left(0.75 \pm 0.06 \mathrm{Mg} \mathrm{ha}^{-1}\right)$ respectively. The cocoa trees on the other hand, at a stocking of 683 trees/ha yielded a total biomass of $6.83 \pm$ $0.19 \mathrm{Mg} \mathrm{ha}^{-1}$, which was still significantly lower than that for the G. sepium $(\mathrm{P}=0.011)$. Stem biomass was found to be $39.09 \%$ (2.67 \pm 0.72 
$\left.\mathrm{Mg} \mathrm{ha}{ }^{-1}\right)$ while branch and foliage biomasses were $30.60 \%\left(2.09 \pm 0.07 \mathrm{Mg} \mathrm{ha}^{-1}\right)$ and $30.31 \%$ $\left(2.07 \pm 0.05 \mathrm{Mg} \mathrm{ha}^{-1}\right)$ respectively.

Whereas the G. sepium produced significantly higher branches biomass per hectare than the cocoa $(P=0.006)$, the cocoa had a significantly higher leaves biomass per hectare than the G. sepium $(\mathrm{P}=0.021)$. There was no significant difference between the stem biomass per hectare for both cocoa and G. sepium $(\mathrm{P}=0.578)$.

TABLE 2

Aboveground biomass partitioning per tree in cocoa and Gliricidia trees in an eight-year-old cocoa agroforest in Bontomuruso, Ghana.

\begin{tabular}{lcccc}
\hline \multirow{2}{*}{ Tree component } & \multicolumn{3}{c}{ Dry weight of tree components (kg/tree) } \\
\cline { 2 - 5 } & \multicolumn{2}{c}{ G. sepium } & \multicolumn{2}{c}{ T. cacao } \\
\cline { 2 - 5 } & Biomass (Kg/tree) & $\begin{array}{c}\text { Proportion } \\
(\%)\end{array}$ & $\begin{array}{c}\text { Biomass (Kg/ } \\
\text { tree) }\end{array}$ & $\begin{array}{c}\text { Proportion } \\
(\%)\end{array}$ \\
\hline Stem & $21.39 \pm 3.79^{\mathrm{a}}$ & 44.34 & $4.93 \pm 0.96^{\mathrm{b}}$ & 40.71 \\
\hline Branches & $22.45 \pm 6.89^{\mathrm{a}}$ & 46.54 & $2.95 \pm 0.47^{\mathrm{b}}$ & 24.36 \\
\hline Leaves & $4.40 \pm 0.66^{\mathrm{a}}$ & 9.12 & $4.63 \pm 1.19^{\mathrm{a}}$ & 38.23 \\
\hline $\begin{array}{l}\text { Total Aboveground } \\
\text { Biomass Kg/tree }\end{array}$ & $48.24 \pm 11.05^{\mathrm{a}}$ & 100 & $12.11 \pm 2.61^{\mathrm{b}}$ & 100 \\
\hline
\end{tabular}

TABLE 3

Distribution of aboveground biomass in cocoa and G. sepium trees of an eight year old cocoa agroforest in Bontomuruso, in the Atwima Mponua district of

Ghana.

\begin{tabular}{|c|c|c|c|c|}
\hline \multirow[b]{3}{*}{ Tree component } & \multicolumn{4}{|c|}{ Stand dry weight values $(t / h a)$} \\
\hline & \multicolumn{2}{|c|}{ G. sepium } & \multicolumn{2}{|c|}{ T. cacao } \\
\hline & $\begin{array}{l}\text { Biomass } \\
\left(M g h a^{-1}\right) \\
\end{array}$ & $\begin{array}{c}\text { Proportion } \\
(\%)\end{array}$ & $\begin{array}{l}\text { Biomass } \\
\left(M h^{-1}\right)\end{array}$ & $\begin{array}{c}\text { Proportion } \\
(\%)\end{array}$ \\
\hline Stocking (trees/ha) & $204^{\mathrm{a}}$ & & $683^{b}$ & \\
\hline Stem & $3.12 \pm 0.18^{\mathrm{a}}$ & 31.10 & $2.67 \pm 0.72^{\mathrm{a}}$ & 39.09 \\
\hline Branches & $6.32 \pm 0.36^{\mathrm{a}}$ & 61.59 & $2.09 \pm 0.07^{\mathrm{b}}$ & 30.60 \\
\hline Leaves & $0.75 \pm 0.54^{\mathrm{a}}$ & 7.31 & $2.07 \pm 0.05^{\mathrm{b}}$ & 30.31 \\
\hline $\begin{array}{l}\text { Total Aboveground } \\
\text { Biomass (t/ha) }\end{array}$ & $10.26 \pm 0.57^{\mathrm{a}}$ & 100 & $6.83 \pm 0.19^{b}$ & 100 \\
\hline
\end{tabular}




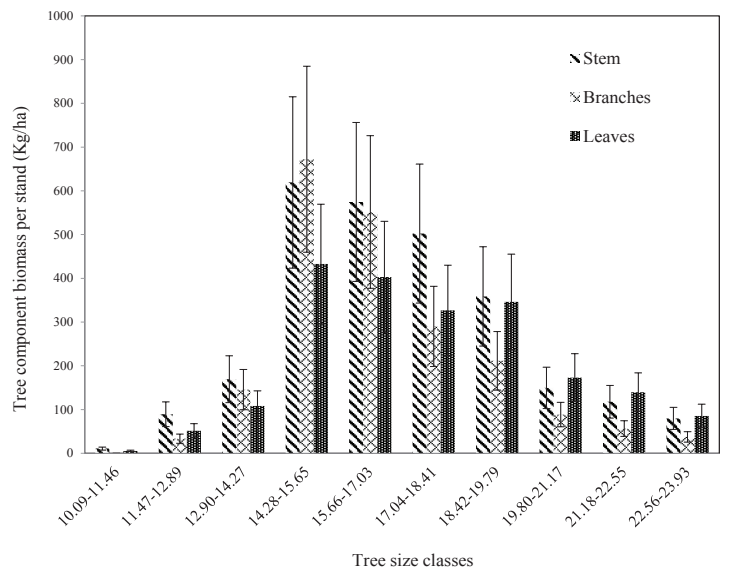

Fig. 1. Biomass distribution in various size classes and tree components of cocoa trees in a cocoa agroforestry system in Ghana.

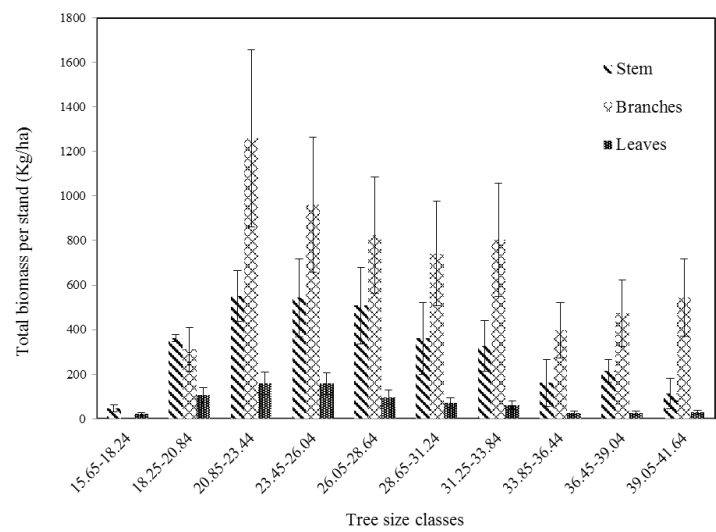

Fig. 2. Distribution of biomass in different size classes and tree components of Gliricidia trees in a cocoa agroforestry system in Ghana.

Carbon storage in the cocoa agroforestry system

The total Carbon content per tree and for a 1 ha stand in both species are shown in Tables 4 and 5 . The total carbon content increased with increasing biomass. Thus eight years after planting, the G. sepium shade trees accumulated more carbon in the branches per tree $(11.22$

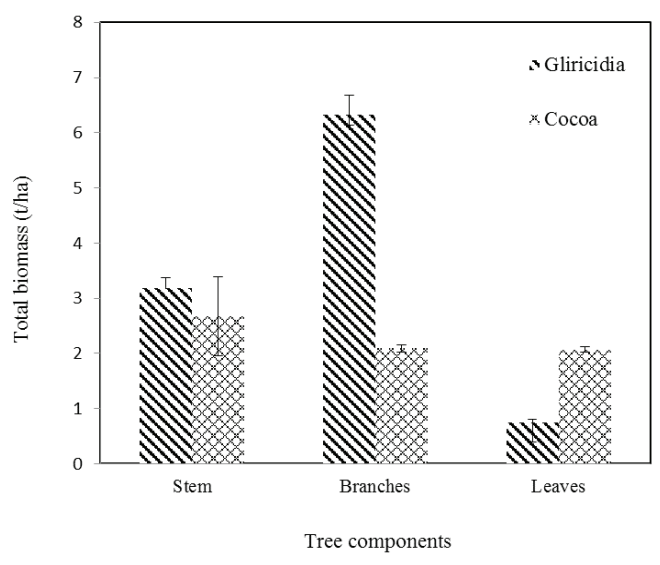

Fig. 3. Biomass distribution within tree components in a cocoa-gliricidia agroforestry system in Ghana.

$\pm 3.45 \mathrm{Kg} \mathrm{C} /$ tree) followed by the stems (10.69 $\pm 1.89 \mathrm{Kg} \mathrm{C} /$ tree), while the leaves recorded the least carbon content of $2.20 \pm 0.33 \mathrm{Kg} \mathrm{C} /$ tree. For the cocoa trees on the other hand, the stem contained the highest carbon content of $2.47 \pm 0.45 \mathrm{Kg} \mathrm{C} /$ tree with the branches containing the least carbon $(1.48 \pm 0.24 \mathrm{Kg} \mathrm{C} /$ tree) and the leaves showing an intermediate carbon content of $2.32 \pm 0.59 \mathrm{Kg} \mathrm{C} /$ tree (Table 4). All the differences between the component dry weights of the $G$. sepium and cocoa trees were significant except the leaves where there was no significant difference between the dry weight/tree of the G. sepium leaves and the cocoa leaves.

For the whole stand, the G. sepium shade trees accumulated a significantly higher total $\mathrm{C}$ content $(\mathrm{P}=0.041)$ of $5.13 \pm 0.09 \mathrm{Mg} \mathrm{C} \mathrm{ha}^{-1}$ than the cocoa trees which accumulated a total of $3.42 \pm 0.09 \mathrm{Mg} \mathrm{C} \mathrm{ha}^{-1}$ in the 8 years. In terms of carbon distribution among stand components, branches contributed the highest carbon content per ha $(3.16 \pm 0.06 \mathrm{Mg} \mathrm{C}$ $\mathrm{ha}^{-1}$ or $61.59 \%$ ) for the G. sepium shade trees, with the leaves contributing the lowest $(0.38 \pm$ 
$0.01 \mathrm{Mg} \mathrm{C} \mathrm{ha}^{-1}$ or $7.41 \%$ ) and the stems having intermediate carbon content $(1.59 \pm 0.03 \mathrm{Mg}$ $\mathrm{C} \mathrm{ha}^{-1}$ or $30.99 \%$ ). Unlike in the G. sepium, the highest carbon content per ha for the cocoa was contributed by the stems $(1.34 \pm 0.04$
$\mathrm{Mg} \mathrm{C} \mathrm{ha-1} \mathrm{or} 39.18 \%$ ), with the branches and leaves containing virtually the same amount of carbon per ha $\left(1.04 \pm 0.04 \mathrm{Mg} \mathrm{C} \mathrm{ha}^{-1}\right.$ and 1.04 $\pm 0.03 \mathrm{Mg} \mathrm{C} \mathrm{ha}^{-1}$ or $30.41 \%$ each, respectively) (Table 5 and Fig. 1).

TABLE 4

Aboveground carbon partitioning per tree in an eight-year-old cocoa Gliricidia agroforest in Bontomuruso, Ghana.

\begin{tabular}{lcccc}
\hline & \multicolumn{3}{c}{ Carbon content of tree components (kg C/tree) } \\
\cline { 2 - 5 } Tree component & \multicolumn{2}{c}{ G. sepium } & \multicolumn{2}{c}{ T. cacao } \\
\cline { 2 - 5 } & $\begin{array}{c}\text { Carbon }(\mathrm{Kg} / \\
\text { tree })\end{array}$ & $\begin{array}{c}\text { Proportion } \\
(\%)\end{array}$ & $\begin{array}{c}\text { Carbon } \\
(\text { Kg/ tree })\end{array}$ & $\begin{array}{c}\text { Proportion } \\
(\%)\end{array}$ \\
\hline Stem & $10.69 \pm 1.89^{\mathrm{a}}$ & 44.35 & $2.47 \pm 0.45^{\mathrm{b}}$ & 39.46 \\
\hline Branches & $11.22 \pm 3.45^{\mathrm{a}}$ & 46.52 & $1.48 \pm 0.24^{\mathrm{b}}$ & 23.54 \\
\hline Leaves & $2.20 \pm 0.33^{\mathrm{a}}$ & 9.13 & $2.32 \pm 0.59^{\mathrm{a}}$ & 37.00 \\
\hline $\begin{array}{l}\text { Total Aboveground } \\
\text { Biomass Kg/tree }\end{array}$ & $24.12 \pm 5.53^{\mathrm{a}}$ & 100 & $6.26 \pm 1.27^{\mathrm{b}}$ & 100 \\
\hline
\end{tabular}

TABLE 5

Distribution of aboveground carbon in an eight-year old cocoa agroforest in Bontomuruso, in the Atwima Mponua district of Ghana.

\begin{tabular}{|c|c|c|c|c|}
\hline \multirow[b]{3}{*}{ Tree component } & \multicolumn{4}{|c|}{ Stand aboveground carbon values $\left(\mathrm{Mg} C \mathrm{~h} \mathrm{a}^{-1}\right)$} \\
\hline & \multicolumn{2}{|c|}{ G. sepium } & \multicolumn{2}{|c|}{ T. cacao } \\
\hline & $\begin{array}{c}\text { Carbon } \\
\left(M g C h a^{-1}\right)\end{array}$ & $\begin{array}{l}\text { Proportion } \\
(\%)\end{array}$ & $\begin{array}{c}\text { Carbon } \\
\left(M g C h a^{-1}\right)\end{array}$ & $\begin{array}{c}\text { Proportion } \\
(\%)\end{array}$ \\
\hline Stocking (trees/ha) & $204^{\mathrm{a}}$ & & $683^{b}$ & \\
\hline Stem & $1.59 \pm 0.03^{\mathrm{a}}$ & 30.99 & $1.34 \pm 0.04^{\mathrm{a}}$ & 39.18 \\
\hline Branches & $3.16 \pm 0.06^{\mathrm{a}}$ & 61.60 & $1.04 \pm 0.04^{\mathrm{b}}$ & 30.41 \\
\hline Leaves & $0.38 \pm 0.01^{\mathrm{a}}$ & 7.41 & $1.04 \pm 0.03^{\mathrm{b}}$ & 30.41 \\
\hline $\begin{array}{l}\text { Total Aboveground Carbon } \\
\left(\mathrm{Mg} \mathrm{Cha}^{-1}\right)\end{array}$ & $5.13 \pm 0.09^{\mathrm{a}}$ & 100 & $3.42 \pm 0.09^{b}$ & 100 \\
\hline
\end{tabular}




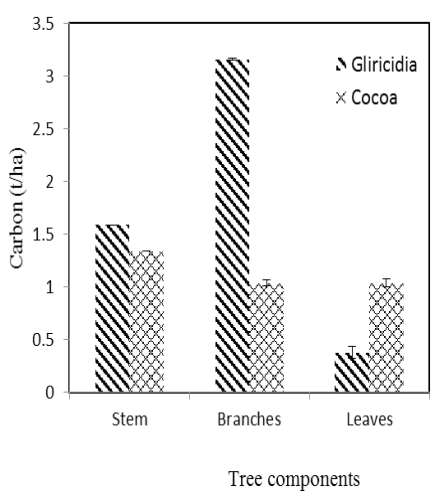

Fig. 4.. Aboveground carbon content and distribution within tree components in a cocoa-gliricidia agroforestry system in Ghana.

\section{Discussion}

\section{Growth parameters of the system}

The initial planting density for cocoa and G. sepium was 1111 and 277 trees ha $^{-1}$ respectively. However, the density of the cocoa at the time of the study, eight (8) years on, was $61.48 \%$, or 683 trees $\mathrm{ha}^{-1}$ of the initial stocking, while that of the G. sepium trees was $73.65 \%$, or 204 trees $\mathrm{ha}^{-1}$, on this site. Compared to a cocoa- G. sepium agroforestry plot of comparable age (i.e. 6 years) in Central Sulawesi, Indonesia, with final stocking of 1030 cocoa trees and $325 \mathrm{G}$. sepium trees ha-1 (Leuschner et al., 2013), the stocking in our study plot was rather low. The mean height of the cocoa and G. sepium of 4.03 $\pm 0.30 \mathrm{~m}$ and $9.26 \pm 0.42 \mathrm{~m}$ respectively, were comparatively lower than the mean tree heights of $4.5 \pm 0.01 \mathrm{~m}$ and $10.1 \pm 0.10 \mathrm{~m}$ obtained for cocoa and $G$. sepium respectively by Leuschner et al. (2013), even though our plot is relatively older by 2 years. This may be due to the higher stocking densities of both cocoa and $G$. sepium in the later study, which would have resulted in competition between the trees for light resulting increased height growth compared to our stand. In these two studies, however, the mean Dbh of the cocoa and G. sepium trees in our plot were much higher $(16.85 \pm 1.35 \mathrm{~cm}$ and 28.33 $\pm 2.47 \mathrm{~cm}$ respectively) than those obtained for the 6-year old plot $(9.5 \pm 0.9 \mathrm{~cm}$ and $12.6 \pm$ $1.4 \mathrm{~cm}$ respectively) in the Central Sulawesi study. The higher Dbh growth attained in our plots may be attributed to the lower densities of both cocoa (683 trees/ha) and G. sepium (204 trees $\mathrm{ha}^{-1}$ ) which gave the trees more growing space for more lateral growth compared to the much higher plant densities of 1030 cocoa trees $\mathrm{ha}^{-1}$ and $325 \mathrm{G}$. sepium trees $\mathrm{ha}^{-1}$ in a plot by Leuschner et al., (2013). The higher height and Dbh values in our plot to lower densities is also supported by Aref et al., (1999) who reported in a study with Leucaena leucocephala (Lam.) de Wit. trees that, increasing stem diameter and height of trees with increasing distance between trees (i.e. lower densities) is simply a result of exploiting the same available belowground resources (water and nutrient) by less number of trees. As pointed out by Clutter et al., (1983) cited by Krieger, (1998), spacing and thinning experiments have consistently shown that stands with wider spacing or stands previously thinned have larger average diameters than similar stands with closer spacing or comparable unthinned stands over time. For the same reason of higher stocking, the basal areas of the cocoa and G. sepium trees in the six year old cocoa agroforest in Central Sulawesi were higher $\left(29.7 \pm 1.6 \mathrm{~m}^{2}\right.$ and $13.8 \pm 1.4$ $\mathrm{m}^{2}$, respectively) than those in our study (16.21 $\pm 1.25 \mathrm{~m}^{2}$ and $10.38 \pm 1.16 \mathrm{~m}^{2}$ for the cocoa and $G$. sepium respectively).

\section{Biomass production}

Wood and leaf biomass production is of more significance in the G. sepium shade trees than in the cocoa since they are grown primarily for wood fuel and for animal fodder, as well as for soil improvement through litter fall in addition to biological nitrogen fixation. 
On an individual tree basis, the larger sized G. sepium trees produced more wood and leaf biomass per tree $(48.24 \mathrm{Kg}$, Table 2) than the cocoa $(12.11 \mathrm{Kg})$. However, on a hectare basis, leaf biomass production was higher in the cocoa than in the G. sepium (2.07 Mg ha ${ }^{-1}$ and $0.75 \mathrm{Mg} \mathrm{ha}^{-1}$ respectively) because of the higher density of the cocoa trees per hectare.

In the G. sepium about half (46.54\%) of the total biomass per tree was allocated to the branches, and this was significantly higher $(\mathrm{P}=0.006)$ than branches biomass in the cocoa trees, with $44.34 \%$ going into the stem and only $9.12 \%$ going into leaf formation. Thus about $90 \%$ of the growth was put into woody biomass. The greater allocation of aboveground biomass into branches formation is of great importance, since this species is grown mainly for fuelwood production. This phenomenon will give a higher fuelwood yield when the shade trees are lopped, pruned or the branches cut back, to control shade levels on the farm. The higher branch biomass in this species is similar to what Nwoboshi, (1996), observed in Eucalyptus alba planted for fuelwood and charcoal production in the Accra plains in Ghana, in which a greater proportion of their biomass was channeled into branches. Adu-Anning \& Anglaaere, (1995), had earlier observed that species with many small stems and branches constituting a greater proportion of the dry matter are more preferred for fuelwood production than those which have greater portions of the biomass being channeled into single stems.

The total aboveground biomass of 6.83 $\pm 0.19 \mathrm{Mg} \mathrm{ha}^{-1}$ obtained for the cocoa trees in this study is slightly higher than the 6.44 $\mathrm{Mg} \mathrm{ha}^{-1}$ and higher than the $5.51 \mathrm{Mg} \mathrm{ha}^{-1}$ total aboveground biomass obtained for cocoa trees in ten years old sparse and dense cocoa agroforests, respectively, in Nigeria by Oke \&
Olatiilu, (2011).This difference may, however, be explained by the difference in the densities of the cocoa trees in the three systems. Whereas the density of cocoa trees in our study was as high as 683 cocoa trees ha-1 that of the sparse cocoa agroforest was 296 cocoa trees/ha while the dense cocoa agroforest contained only 232 cocoa trees ha ${ }^{-1}$, and could have accounted for our higher total stand aboveground biomass. However, there was a big difference in the partitioning of the biomass among the stand components whereas stem biomass accounted for as much as $83.98 \%$ and $87.11 \%$ of the total aboveground cocoa biomass in the sparse and dense cocoa agroforest, respectively, in Nigeria (Oke \& Olatiilu, 2011), it accounted for only $39.1 \%$ total aboveground biomass of the cocoa trees in our study. And whereas the branches and foliage biomass was equally partitioned (30.6\% and $30.3 \%$ respectively) in our study, the ten years old cocoa trees in Nigeria had $12.60 \%$ and $3.42 \%$ of total stand biomass allocated to branches and foliage respectively in the sparse cocoa agroforest, and $10.53 \%$ and $2.40 \%$ allocated to branches and foliage respectively in the dense cocoa agroforest (Oke $\&$ Olatiilu, 2011). This difference in biomass partitioning may be due to difference in the age of the cocoa stands ( 8 years in our study and 10 years in the Nigeria study). The older cocoa trees would have developed bigger and more lignified boles and branches than those in our younger stand. Nevertheless, the biomass partitioning still followed the same pattern as that obtained by Oke \& Olatiilu (2011), i.e. stems $>$ branches $>$ foliage. The total stand biomass of $17.09 \mathrm{Mg} \mathrm{ha}^{-1}$ (G. sepium and cocoa trees together) at this site is, however, lower than the $40.92 \mathrm{Mg} \mathrm{ha}^{-1}$ and $39.30 \mathrm{Mg} \mathrm{ha}^{-1}$ biomass reported by Mainoo \& Ulzen-Appiah, (1996), for G. sepium and L. leucocephala, respectively, though this will be more due to 
the much higher stand density of 8333 trees/ha for these species, established at the Institute of Renewable Natural Resources farm, KNUST, Kumasi.

\section{Carbon content}

In terms of carbon storage of the system, the inclusion of $G$. sepium also increased carbon content by $5.13 \mathrm{Mg} \mathrm{C} \mathrm{ha}^{-1}$, over the sole cocoa carbon content of $3.41 \mathrm{Mg} \mathrm{C} \mathrm{ha}^{-1}$, to a total of $8.54 \mathrm{Mg} \mathrm{C} \mathrm{ha}^{-1}$. This compares very well with figures reported for 8 year old pure plantations of Azadirachta indica (8.0 Mg C ha $^{-1}$ ) by Evans, (1982) and Pandey, (1983), and demonstrates that multi-strata cocoa agroforestry systems present substantial potential for capturing and storing atmospheric carbon. The carbon estimate values obtained in this study compared favourably with estimates reported for other pure tropical forest plantations of varying and comparable ages. For example, the total woody carbon content (stem and branches) of $7.13 \mathrm{Mg} \mathrm{C}^{-1}$ (i.e. $4.75 \mathrm{Mg} \mathrm{C}^{-1}$ for G. sepium and $2.38 \mathrm{Mg} \mathrm{C}^{-1}$ for cocoa) accumulated by this 8 year old agroforest compares well to estimates of $8 \mathrm{MgC} \mathrm{ha}^{-1}$ reported by Evans, (1982) and Pandey, (1983) for an 8 year old pure plantation of $A$. indica. Our results are also comparable with results obtained in a study by Rizvi et al., (2011), who recorded a standing/total carbon stock of 3.78-1.62 Mg $\mathrm{C} \mathrm{ha}^{-1}$ under poplar-based agroforestry systems in the upper Gangetic region, where 70 million poplar trees planted with agricultural crops. In a study conducted to assess carbon accumulation in agroforestry systems in India, Singh \& Lodhiyal, (2009), estimated carbon stock in Populus deltoids agroforestry plantations of the same age as our stand (8-year-old) to be 47.86 $\mathrm{Mg} \mathrm{C} \mathrm{ha}^{-1}$ in bole wood alone and 96.23 $\mathrm{Mg} \mathrm{C} \mathrm{ha-1} \mathrm{in} \mathrm{total} \mathrm{biomass} \mathrm{of} \mathrm{trees,} \mathrm{but} \mathrm{this}$ higher carbon may be due to the fact that $P$. deltoids is inherently a much larger tree than G. sepium, apart from possible higher stocking densities in their plantations.

A number of studies have demonstrated that cocoa agroforestry systems have a greater potential for accumulating and storing more biomass and carbon than sole cocoa systems. In tropical Central America, Somarriba et al., (2013), assessed carbon stocks in various agroforestry systems. In 24-years old cocoa farms, they obtained a total aboveground biomass carbon stock for a mixed shade cocoa system to be $49.2 \mathrm{Mg} \mathrm{C} \mathrm{ha}^{-1}$, and for a cocoa-Erythrina fusca agroforestry system to be $32 \mathrm{Mg} \mathrm{C}$ $\mathrm{ha}^{-1}$. The carbon stock of a sole cocoa system of the same age was found to be only $9.0 \mathrm{Mg}$ $\mathrm{C} \mathrm{ha}^{-1}$. In Cameroon, Gockowski \& Sonwa, (2011), evaluated aboveground carbon stocks of a 40 year-old cocoa-timber agroforestry and a pure cocoa system of the same age. The cocoa-timber system accumulated $89 \mathrm{Mg} \mathrm{C} \mathrm{ha}^{-1}$ while the sole cocoa system accumulated only $49 \mathrm{Mg} \mathrm{C}^{-1}$. Back here in Ghana, Wada et al., (2010), obtained values of $131 \mathrm{Mg} \mathrm{C} \mathrm{ha}^{-1}$ for a 50 year-old traditional cocoa system ( $>25 \%$ shade) $10 \mathrm{Mg} \mathrm{C}^{-1}$ for a shadeless cocoa farm of the same age. In this study, the 8 year-old cocoa- Gliricidia agroforestry system accumulated a total of $8.54 \mathrm{Mg} \mathrm{C}^{-1}$, while without the shade trees the pure stand of cocoa alone would have accumulated only $3.41 \mathrm{Mg} \mathrm{C} \mathrm{ha}^{-1}$. Thus all these studies have demonstrated that the inclusion of shade trees in cocoa greatly enhances the biomass and carbon storage potential of the system.

\section{Conclusion}

Results of the accumulation of above-ground biomass in the cocoa-Gliricidia agroforestry system indicated that the inclusion of the $G$. sepium shade trees increased the above-ground biomass of the system by $60.04 \%$, and a great- 
er proportion of this biomass was contained in the branches of the shade trees. This pattern of dry matter distribution makes the species appropriate for growing as a biomass producing species in agroforestry systems. The inclusion of $G$. sepium also increased carbon capture compared with the sole cocoa system, and demonstrates that cocoa agroforestry systems have the potential for capturing and storing more atmospheric carbon than sole crop (cocoa) systems.

\section{Acknowledgements}

This paper was written from the final year undergraduate project of the first author. The authors are grateful to the Director and management of CSIR-FORIG for financial and logistical support, and to field staff in Bontomuruso for support with fieldwork. The authors are grateful to Cadbury Ghana for permission to carry out the study on their research farm.

\section{REFERENCES}

Abrahamson, L. P., Robison, D. J., Volk, T. A., White, E. H., Neuhauser, E. F., Benjamin, W. H. \& Peterson, J. M. (1998) Sustainability and environmental issues associated with willow bioenergy development in New York (U.S.A.). In: Biomass and Bioenergy 15 (1), 17 - 22.

Adams, S. N. (1962) Cocoa: Soils and Manuring. In: Wills, J. B. (ed.), Agriculture and Land Use in Ghana. Oxford University Press. pp. $266-273$.

Adu-Anning,C. \& Anglaaere, L. C. N. (1995) Growth, energy yield and nutrient uptake of some fuelwood species in the Sudan savanna of Ghana. Journal of Tree Sciences 14 (1), 23 -31.

Afas, N. A., Marron, N., van Dongen, S., Laureysens, I. \& Ceulemans, R. (2008) Dynamics of biomass production in a poplar coppice culture over three rotations (11 years). In: Forest Ecology and Management 255 (5-6), 1883 - 1891.
Albrecht, A. \& Kandji, S. T. (2003) Carbon sequestration in tropical agroforestry systems. Agric. Ecosyst. Environ. 99, 15 - 27.

Ayanjala, S. A. (1983) Rehabilitation of cocoa (Theobroma cacao L.) in Nigeria.Major problems and possible solutions. I. Causes of difficulty of seedling establishment. Plant and Soils 73 (3), $403-409$.

Brown, S. \& Lugo, A. E. (1982) The Storage and Production of Organic Matter in Tropical Forests and Their Role in the Global Carbon Cycle. Biotropica 14 (2), 161 - 187.

Cleaver, K. (1992) Deforestation in the western and Central African rainforest: the agricultural and demographic causes, and some solutions. In: Cleaver K, Munasinghe M, Dyson M, Egli N, Penker A, \& Wencelius F (eds) Conservation of west and central African rainforests. The World Bank/International Union for the Conservation of Nature, Washington. pp. $65-78$

Dhyani, S. K., Ram Newaj \& Sharma, A. P. (2009) Agroforestry: its relation with agronomy, challenges and opportunities. Indian J. Agron 54 (3), $249-266$.

Dixon, R. K. (1995) Agroforestry systems: sources or sinks of greenhouse gases? Agroforestry Systems 31, $99-116$.

Duguma, B., Gockowski, J. \& Bakala, J., (2001) Smallholder cacao (Theobroma cacao Linn.) cultivation in agroforestry systems of west and central Africa: challenges and opportunities. Agroforestry Systems 51, 177 - 188.

Fang, S., Xue, J. \& Tang, L. (2007) Biomass production and carbon sequestration potential of poplar plantations with different management patterns. J. Environ. Manage 85 (3), 672 - 679.

Evans, J. (1982) Plantation Forestry in the Tropics. Clarendon Press, Oxford, UK. pp. 472.

Gockowski, J. \& Sonwa, D. (2011) Cocoa intensification scenarios and their predicted impact on $\mathrm{CO} 2$ emissions, biodiversity conservation, and rural 
livelihoods in the Guinea rain forest of West Africa. Environ. Manage 48, 307 - 321.

Gutteridge, R. C. \& Shelton, H. M. (1994) Forage Tree Legumes in Tropical Agriculture. Wallingford: CAB International.

Hall, J. B. \& Swaine, M. D. (1981) Distribution and Ecology of Vascular Plants in a Tropical Rainforest. Junk, The Hague.

IPCC (2007) Climate Change 2007 - synthesis report, Geneva.

Jose, S. (2009) Agroforestry for ecosystem services and environmental benefits: An overview. Agroforestry Systems 76, 1 - 10.

Jose, S. \& Bardhan, S. (2012) Agroforestry for biomass production and carbon sequestration: an overview. Agroforestry Systems 86,105 - 111.

Krieger, C. (1998) The Effects of Tree Spacing on Diameter, Height and Branch Size in White Spruce. MANAGEMENT NOTES Number 13. pp. 12.

Leuschner, C., Moser, G., Hertel, D., Erasmi, S., Leitner, D., Culmsee, H., Schuldt, B. \& Schwendenmann, L. (2013) Conversion of tropical moist forest into cacao agroforest: consequences for carbon pools and annual C sequestration. Agroforest Syst 87, 1173-1187.

Lodhiyal, L. S., Singh, R. P. \& Rana, B. S. (1992) Biomass and productivity in an age series of short rotation Populus deltoids plantations. Trop. Ecol. 33 (2), 214-222.

Lodhiyal, L. S., Rana, B. S. \& Singh, R. P. (1995) Dry matter production in a poplar (Populus deltoids Marsh) plantation of Central Himalayan Tarai. Indian For 121, 383 - 89.

Mainoo, A. A. \& Ulzen-Appiah, F. (1996) Growth, wood yield and energy characteristics of Leucaenaleucocephala,Gliricidiasepium and Sennasiamea at age four years. Ghana Journal of Forestry 3, $69-79$.
Montagnini, F. \& Nair, F. P. K. R. (2004) Carbon sequestration: an underexploited environmental benefit of agroforestry systems. Agroforestry Systems 61, $281-295$.

Nair, P. K. R., Kumar, B. M. \& Nair, V. D. (2009) Agroforestry as a strategy for carbon sequestration. J. Plant Nutr. Soil Sci.172, 10-23.

Negi, M. S. \& Tandon, V. N. (1997) Biomass and nutrient distribution in an age sequence of $P$ Poplusdeltoides ecosystem in Haryana. Indian For 123, 111-117.

Nolte, C., Tiki-Manga, T., Badjel-Badjel, J., Gockowski, J., Hauser, S. \& Weise, S. F. (2003) Effects of calliandra planting pattern on biomass production and nutrient accumulation in planted fallows of Southern Cameroon. Forest Ecology and Management 179, 535 - 545.

Nwoboshi, L. C. (1985) Biomass and nutrient uptake and distribution in a Gmelinaarborea pulpwood plantation age series in Nigeria. Journal of Tropical Forest Resources 1 (1), 53 - 61.

Nwoboshi, L. C. (1996) Growth and energy yield of some fuelwood species in the Accra plains of Ghana. Ghana Journal of Forestry 2, 6-9.

Oke, D. O. \& Odebiyi, K. A. (2007) Traditional cocoa-based agroforestry and forest species conservation in Ondo State, Nigeria. Agric. Ecosyst. Environ. 122, 305 - 311. doi:10.1016/j. agee.2007.01.022

Oke, D. \& Olatiilu, A. (2011). Carbon Storage in Agroecosystems: A Case Study of the Cocoa Based Agroforestry in Ogbese Forest Reserve, Ekiti State, Nigeria. Journal of Environmental Protection 2, 1069 - 1075.

Otsyina, R. M. (1989) Consultancy in Agroforestry. Government of Ghana/UNDP/FAO Publication, Accra, Ghana. pp. 44.

Pandey, D. (1983) Growth and yield of plantation species in the tropics. Forest Resources Division, FAO, Rome, Italy. pp. 115. 
Poorter, H., Niklas, K. J., Reich, P. B., Oleksyn, J., Poot, P. \& Mommer, L. (2012) Biomass allocation to leaves, stems and roots: meta-analyses of interspecific variation and environmental control. New Phytologist 193, 30 - 50. doi:10.1111/ j.1469-8137.2011.03952.x

Quashi-Sam, S. J., Dunn, J., Dampson, J. H., Minae, S. \& Avila, M. (1990) Agroforestry potential and research for the land use system in the humid lowlands of Ghana. AFRENA report 34 ICRAF, Nairobi, Kenya. pp. 104.

Ravindranath, N. H., Somashekhar, B. S. \& Gadgil, M. (1997) Carbon Flow in India Forests. Climatic Change 35, 297-320.

Rizvi, R. H., Dhyani, S. K., Yadav, R. S. \& Singh, R. (2011) Biomass production and carbon stock of poplar agroforestry systems in Yamunanagar and Saharanpur districts of north-western India. Current Science 100 (5), 736 - 742.

Robinson, P. J. (1985) Trees as fodder crops. In M. G. R. Cannell and J. E. Jackson (Eds), Attributes of Trees as Crop Plants. Penicuik, Scotland: Institute of Terrestrial Ecology. pp. 281-300.

Schroeder, P. (1994) Carbon storage benefits of agroforestry systems. Agroforestry Systems 27, 89 97.

Schroeder, P. (1992) Carbon Storage Potential of Short Rotation Tropical Tree Plantations. Forest Ecology and Management 50 (1-2), 31- 41

.Singh, P. \& Lodhiyal, L. S. (2009) Biomass and carbon allocation in 8-year-old poplar (Populus deltoids Marsh) plantations in tarai agroforestry systems of Central Himalaya, India. NY Sci. J 2 (6), $49-53$.

Smiley, G. L. \& Kroschel, J. (2008) Temporal change in carbon stocks of cocoa-Gliricidia agroforests in Central Sulawesi, Indonesia. Agroforestry Systems 73, $219-231$
Snowdown, P., Raison, J., Keith, H., Ritson, P., Grierson, P., Adams, M., Montagu, K., Bi, H., Burrows, W. \& Eamus, D. (2002) Protocol for Sampling Tree and Stand Biomass. National Carbon Accounting System, Technical Report No. 31, March 2002.

Somarribaa, E, Cerdaa, R., Orozcoa, L., Cifuentesa, M., Dávilaa, H., Espina, T., Mavisoya, H., Ávilaa, G., Alvaradoa, E., Povedaa, V., Astorgaa, C., Saya, E. \& Deheuvelsb, O. (2013) Carbon stocks and cocoa yields in agroforestry systems of Central America. Agriculture, Ecosystems and Environment 173, 46 - 57.

Soto-Pinto, L., Anzueto, M., Mendoza, J., Jimenez Ferrer, G. \& de Jong, B. (2010) Carbon sequestration through agroforestry in indigenous communities of Chiapas, Mexico. Agroforestry Systems 78, $39-51$.

Stephens, J. (2006) Growing Interest in Carbon Capture and Storage (CCS) for Climate Change Mitigation. Sustainability: Science, Practice and Policy 2 (2), 4-13.

Tandon, V. N., Pandey, M. C., Rawat, H. S. \& Sharma, D. C. (1991) Organic productivity and mineral cycling in plantations of Populus deltoids in Tarai region of Uttar Pradesh. Indian For 117 (8), 596-608.

Taylor, C. J. (1960) Synecology and Silviculture in Ghana. Thomas Nelson and Co., London, UK.

Tscharntke. T., Clough, Y., Bhagwat, S. A., Buchori, D., Faust, H., Hertel, D., Hölscher, D., Juhrbandt, J., Kessler, M., Perfecto, I., Scherber, C., Schroth, G., Veldkamp, E., \& Wanger, T. C. (2011) Multifunctional shade-tree management in tropical agroforestry landscapes - a review. J. Appl. Ecol 4, $619-629$.

Wade, A. S. I., Asase, A., Hadley, P., Mason, J., Ofori-Frimpong, K., Preece, D., Spring, N., \& Norris, K. (2010) Management strategies for maximizing carbon storage and tree species diversity in cocoa-growing landscapes. Agric. Ecosyst. Environ. 138, 324 - 334. 